\title{
Hypoxia-activated chemotherapeutic TH-302 enhances the effects of VEGF-A inhibition and radiation on sarcomas
}

\author{
C Yoon ${ }^{1}$, H-J Lee ${ }^{2,3}$, D J Park ${ }^{1,4}$, Y-J Lee ${ }^{2,3}$, W D Tap ${ }^{5}$, T S K Eisinger-Mathason ${ }^{6}$, C P Hart ${ }^{7}$, E Choy $^{8}$,
} M C Simon 6,9 and S S Yoon*,1

${ }^{1}$ Department of Surgery, Memorial Sloan-Kettering Cancer Center, H-1209, 1275 York Avenue, New York, NY 10021, USA; ${ }^{2}$ Department of Surgery, Massachusetts General Hospital and Harvard Medical School, Boston, MA 02114, USA; ${ }^{3}$ Division of Radiation Effects, Korea Institute of Radiological and Medical Sciences, Seoul, South Korea; ${ }^{4}$ Department of Surgery, Seoul National University Bundang Hospital, Sungnam, South Korea; ${ }^{5}$ Department of Medicine, Memorial Sloan-Kettering Cancer Center, New York, NY 10065, USA; ${ }^{6}$ Abramson Family Cancer Research Institute, Perelman School of Medicine, University of Pennsylvania, Philadelphia, PA 19104, USA; ${ }^{7}$ Threshold Pharmaceuticals, South San Francisco, CA 94080, USA; ${ }^{8}$ Department of Medicine, Massachusetts General Hospital and Harvard Medical School, Boston, MA 02114, USA and ${ }^{9}$ Howard Hughes Medical Institute, Chevy Chase, MD, USA

Background: Human sarcomas with a poor response to vascular endothelial growth factor-A (VEGF-A) inhibition and radiation therapy (RT) have upregulation of hypoxia-inducible factor $1 \alpha$ (HIF-1 $\alpha)$ and HIF-1 $\alpha$ target genes. This study examines the addition of the hypoxia-activated chemotherapy TH-302 to VEGF-A inhibition and RT (a.k.a. trimodality therapy).

Methods: Trimodality therapy was examined in two xenograft models and in vitro in tumour endothelial cells and sarcoma cell lines.

Results: In both mouse models, VEGF-A inhibition and radiation showed greater efficacy than either therapy alone in slowing sarcoma growth. When TH-302 was added, this trimodality therapy completely blocked tumour growth with tumours remaining dormant for over 3 months after cessation of therapy. Trimodality therapy caused 2.6- to 6.2-fold more endothelial cell-specific apoptosis than bimodality therapies, and microvessel density and HIF-1 $\alpha$ activity were reduced to $11-13 \%$ and $13-20 \%$ of control, respectively. When trimodality therapy was examined in vitro, increases in DNA damage and apoptosis were much more pronounced in tumour endothelial cells compared with that in sarcoma cells, especially under hypoxia.

Conclusions: The combination of TH-302, VEGF-A inhibition, and RT is highly effective in preclinical models of sarcoma and is associated with increased DNA damage and apoptosis in endothelial cells and decreased HIF-1 $\alpha$ activity.

Sarcomas account for over $20 \%$ of all pediatric solid malignancies and $<1 \%$ of adult solid malignancies (Lahat et al, 2008). The majority of sarcomas occur in the soft tissues such as fat, muscle, and connective tissue, with bone sarcomas comprising just over $10 \%$ of sarcomas. Sarcomas can be quite lethal with patients dying of either locoregional disease or distant metastasis. The treatment of primary sarcomas generally includes aggressive surgical resection and RT. Despite aggressive local treatment, recurrence remains a problem, especially for tumours in difficult locations such as the head and neck, paraspinal region, retroperitoneum, and pelvis (Brennan et al, 2013). Up to $50 \%$ of patients with large, high-grade sarcomas also develop distant metastases, most frequently to the lung. The effectiveness of adjuvant chemotherapy in preventing local and distant recurrence is modest at best (Schuetze and Patel, 2009).

*Correspondence: Dr SS Yoon; E-mail: yoons@mskcc.org

Revised 23 April 2015; accepted 29 April 2015; published online 26 May 2015

(c) 2015 Cancer Research UK. All rights reserved 0007-0920/15 
Common to most solid tumours are areas of hypoxia and the requirement to generate new tumour blood vessels (Bertout et al, 2008). Tumours respond to hypoxic stress through multiple mechanisms including the stabilisation of hypoxia-inducible factor $1 \alpha$ (HIF-1 $\alpha$ ) (Semenza, 1999). Stabilised HIF-1 $\alpha$ is transported to the nucleus where it binds hypoxia response element (HRE) DNA sequences and activates the expression of at least 150 genes, including genes that drive changes in tumour angiogenesis (e.g. vascular endothelial growth factor-A (VEGF-A)) (Bertout et al, 2008) and cellular metabolism (e.g. carbonic anhydrase 9, CA9) (Potter and Harris, 2004).

Vascular endothelial growth factor A (VEGF-A) is one of the most important factors promoting tumour angiogenesis (Dvorak, 2002). Expression of VEGF-A in sarcomas correlates with extent of disease and survival (Hoffmann et al, 2009). Circulating levels of VEGF-A are elevated on average 10-fold in sarcoma patients compared with controls (Yoon et al, 2004), and inhibition of VEGF-A or its receptors can effectively suppress tumour angiogenesis in mouse models of sarcoma (Detwiller et al, 2005; Yoon et al, 2009). In patients with advanced sarcomas, pazopanib, an orally available tyrosine kinase inhibitor of VEGF receptors 1-3 (VEGFR1-3), was shown in a phase III randomised trial to increase progression-free survival over placebo by nearly 3 months (van der Graaf et al, 2012).

As noted earlier, RT is often used to aid in the local control of difficult sarcomas, and anti-VEGF-A agents may increase the efficacy of RT. Indeed, numerous preclinical studies have examined the combination of anti-VEGF-A agents and radiation against human and murine tumours grown in animal models (Wachsberger et al, 2003; Shannon and Williams, 2008). Near uniformly, these studies show that anti-VEGF-A combined with radiation inhibits tumours better than either therapy alone. We performed a phase II clinical trial of neoadjuvant bevacizumab, an anti-VEGF-A antibody, and RT for patients with resectable sarcomas (Yoon et al, 2011). Bevacizumab and radiation resulted in a good response (defined as $\geq 80 \%$ pathologic necrosis) in nearly half of tumours. Analysis of pretreatment tumour biopsies by gene expression microarrays using Gene Set Enrichment Analysis found the Gene Ontology (GO) category 'Response to hypoxia' was upregulated in tumours that did not respond well to bevacizumab and radiation (Kim et al, 2013).

TH-302 is a 2-nitroimidazole-linked prodrug of a brominated version of isophosphoramide mustard (Br-IPM) (Duan et al, 2008; Sun et al, 2012a).This molecule is relatively inert under normoxic conditions but reduced under hypoxic conditions, leading to the release of Br-IPM, which then acts as a DNA-alkylating chemotherapeutic. In this current study, we examine the effects of adding the hypoxia-activated chemotherapeutic, TH-302, to VEGF-A inhibition and RT in two xenograft models of sarcoma.

\section{MATERIALS AND METHODS}

Cell lines and reagents. HT1080 human fibrosarcoma cells and SK-LMS-1 human leiomyosarcoma cells were obtained from the America Type Culture Collection (ATCC, Manassa, VA, USA). MS4515 and MS5907 mouse undifferentiated pleomorphic sarcoma cell lines were derived from genetically engineered mouse models, which we have described previously (Kirsch et al, 2007). All sarcoma cell lines were maintained in Dulbecco's modified Eagle's medium supplemented with $10 \%$ fetal bovine serum, $100 \mathrm{U} \mathrm{ml}^{-1}$ penicillin, $100 \mu \mathrm{g} \mathrm{ml}^{-1}$ streptomycin, and L-glutamine $2 \mathrm{~mm}$. Human cancer cell lines were actively passaged for $<6$ months from the time that they were received from ATCC, and United Kingdom Co-ordinating Committee on Cancer Research (UKCCCR) guidelines were followed (UKCCCR, 2000). Human umbilical vein endothelial cells (HUVECs) were obtained from Lonza (Basel, Switzerland) and used within eight passages. All endothelial cells were grown in EGM-2-MV media (Lonza).

The anti-VEGFR2 antibody DC101 was purchased from Bio X Cell (West Lebanon, NH, USA). Immunoglobulin G antibody was purchased from Sigma-Aldrich (St Louis, MO, USA). Doxorubicin was purchased from Teva Pharmaceuticals (Tikva, Israel). TH-302 was obtained from Threshold Pharmaceuticals (South San Francisco, CA, USA).

Mouse studies. All mouse protocols were approved by Institutional Animal Care and Use Committee. To generate subcutaneous flank tumour, $1 \times 10^{6}$ HT1080 or SK-LMS-1 cells were resuspended in $100 \mu \mathrm{l}$ of Hank's balanced salt solution and injected subcutaneously into the right flank of athymic, nude, 6- to 8-weekold male BALB/c nu/nu mice following isoflurane anaesthesia. Mice were assigned into treatment groups (5-6 mice per group) when tumours reached $50-100 \mathrm{~mm}^{3}$ in volume, designated as day 0 . DC101 $\left(20 \mathrm{mg} \mathrm{kg}^{-1}\right)$ or isotype control $\operatorname{IgG}_{1} \mathrm{~s}\left(20 \mathrm{mg} \mathrm{kg}^{-1}\right)$ was injected intraperitoneally three times a week. TH-302 $50 \mathrm{mg} \mathrm{kg}^{-1}$ was delivered by intraperitoneal injection 5 days per week. For tumours that were irradiated, radiation was delivered on day 0 . Mice were anaesthetised using ketamine $\left(125 \mathrm{mg} \mathrm{kg}^{-1}\right)$ and xylazine $\left(10 \mathrm{mg} \mathrm{kg}^{-1}\right)$, placed in shielded device to expose only the flank tumour, and irradiated using a Gammacell 40 Exactor Irradiator (Best Theratronics, Ottawa, ON, Canada). When mice were treated with combination therapies, DC101 or control IgG was delivered first and TH-302 and/or radiation were delivered within $2 \mathrm{~h}$ of DC101 administration (Truman et al, 2010). For trimodality therapy, DC101 was administered followed by radiation, and then by TH-302. Tumour volume (TV) was calculated by using the following formula: TV $=$ length $\times(\text { width })^{2} \times 0.52$.

Immunohistochemistry and immunofluorescence. Mice were killed and tumours were harvested immediately and placed into $10 \%$ formalin for $2-3$ days at $4{ }^{\circ} \mathrm{C}$. Tumours were then rinsed and stored in saline and sent to our pathology core facility. Formalinfixed, paraffin-embedded sections were deparaffinised by xylene and rehydrated. Immunohistochemistry was performed with Vectastain Elite ABC Kit (Vector Laboratories, Burlingame, CA, USA) as per the manufacturer's protocol. For antigen retrieval, the sections were placed in citrate buffer $(\mathrm{pH}$ 6.0) and heated in a microwave oven for $10 \mathrm{~min}$. For immunoperoxidase labelling, endogenous peroxidase was blocked by $0.3 \% \mathrm{H}_{2} \mathrm{O}_{2}$ in absolute methanol for $15 \mathrm{~min}$ at room temperature. The sections were then incubated overnight at $4{ }^{\circ} \mathrm{C}$ with primary antibody and washed with PBS containing $0.05 \%$ Triton X-100. Incubation with corresponding secondary antibody and the peroxidaseantiperoxidase complex were carried out for $30 \mathrm{~min}$ at room temperature. Immunoreactive sites were visualised by $3,3^{\prime}$-DAB. Later, the slices were counterstained by haematoxylin. Antibodies used were anti-TUNEL (ApoptoTag Peroxidase Kit; EMD Millipore, Temecula, CA, USA), anti-HIF- $1 \alpha$ (Ab-4; Novus Biologicals, Littleton, CO, USA), anti-CA9 (NB100-417; Novus), and antiPCNA (sc-56; Santa Cruz Biotechnology, Dallas, TX, USA)

CD31 immunohistochemical localisation and analysis of microvessel density were performed as described previously (Fernando et al, 2008). For detection of EC apoptosis, TUNEL and CD31 immunofluorescence was performed as described previously (Kim et al, 2013). Four tumours from each treatment group were analysed for total apoptosis, endothelial cell-specific apoptosis, microvessels density, HIF- $1 \alpha$ expression, and CA9 expression. Hypoxia in tumours was measured using the Hypoxyprobe-1 Kit (HPI, Burlington, MA, USA) as per the manufacturer's instructions.

For examination of cells for $\gamma \mathrm{H} 2 \mathrm{AX}, \mathrm{CD} 31$ and cleaved caspase3 , cells were fixed with $4 \%$ paraformaldehyde and permeabilised with $0.1 \%$ Triton X-100 in PBS. Cells were incubated with the 
appropriate primary antibody in a solution of PBS with $1 \%$ BSA and $0.1 \%$ Triton $\mathrm{X}-100$ at $4{ }^{\circ} \mathrm{C}$ overnight. Antibodies used were as follows: human anti- $\gamma \mathrm{H} 2 \mathrm{AX}$ (mouse polyclonal antibody, $1: 100$, 05-636; EMD Millipore, Billerica, MA, USA), anti-cleaved caspase3 (rabbit polyclonal antibody, $1: 100$, no. 9661; Cell Signalling Technology, Beverly, MA, USA), and anti-CD31 (rat monoclonal antibody, 1:00, DIA-310; Dianova, Hamburg, Germany). Cells were then stained with anti-rat Alexa Flour 488, anti-rabbit Alexa Flour 594, and anti-mouse Alexa Flour 647 (Life Technologies, Norwalk, CT, USA). After $2 \mathrm{~h}$, nuclei were counterstained using DAPI (Sigma-Aldrich). Stained cells were visualised with an inverted confocal microscope (Leica Microsystems, Buffalo Grove, IL, USA). Image processing was performed using the Imaris 7.6 software (Bitplane, Zurich, Switzerland).

Comet assay. The single-cell gel electrophoresis assay, also known as the Comet assay, was carried out using Comet Assay Kit (Trevigen Inc., Gaithersburg, MD, USA) as per the manufacturer's instructions. Bleomycin was not added. Olive tail moment values (equal to the product of the tail length and the fraction of total DNA in the tail) were calculated from at least 50 cells for each group using the Komet 5.5 software (Andor Technology, Belfast, UK).

Tumour endothelial cell isolation. Tumour endothelial cell were harvested from HT1080 xenografts. When tumours reached 100$150 \mathrm{~mm}^{3}$ in size, they were removed, minced, and digested in $25 \mathrm{ml}$ of prewarmed collagenase I ( $2 \mathrm{mg} \mathrm{ml}^{-1}$; EMD Millipore) in PBS for $45 \mathrm{~min}$ at $37^{\circ} \mathrm{C}$. Cells were strained through a $100 \mu \mathrm{m}$ strainer, and collagenase activity was quenched with $10 \mathrm{ml}$ of isolation medium (DMEM (high glucose $4500 \mathrm{mgl}^{-1}$ ) $+20 \%$ FCS + Pen/ Strep). Cells were resuspended in $5 \mathrm{ml}$ of cold sterile PBS with $0.1 \%$ BSA, followed by centrifugation at $400 \mathrm{~g}$ for $8 \mathrm{~min}$. The cloudy interface containing endothelial cells was removed and washed with sterile PBS containing $0.5 \%$ BSA. Cells were then resuspended in $400 \mathrm{ml}$ PBS containing $0.5 \%$ BSA. A measure of $2.5 \mu \mathrm{l}$ of $1 \mu \mathrm{g} \mathrm{ml}$ anti-mouse CD31 (ab28364; Abcam, Cambridge, MA, USA) was added to the cell suspension and incubated for $20 \mathrm{~min}$ at room temperature. After using Dynal beads coated with CD31 antibody (110.35; Life Technologies), the cells were plated into a gelatincoated T-75 flask. After 1-2 weeks (or if the attached cell clones are observed in dish), cells were used for experiments between passages 2 and 6 as described previously (Ryeom et al, 2008).

Proliferation and colony formation assays. To assay for proliferation, 3000 cells were plated onto 24-well plates and maintained in media overnight. A colorimetric MTT assay was used to assess cell number by optical density after 3 days as described previously (Yoon et al, 1999). Data reflect the mean of six samples.

To assay for colony forming ability, 200-500 cells were plated onto $60 \mathrm{~mm}$ culture dishes and incubated for 7-14 days. Colonies were stained with $0.5 \%$ crystal violet in $6 \%$ glutaraldehyde solution. The number of colonies consisting of 50 or more cells was scored. Data reflect the mean of nine samples.

Hypoxia was created by placing cells into Heracell 150i Tri-Gas Incubator (Thermo Scientific, Waltham, MA, USA) with $1 \%$ oxygen, $94 \%$ nitrogen, and $5 \% \mathrm{CO}_{2}$. Each experiment was performed at least three times.

Irradiation of cells. Cells were exposed to a ${ }^{137} \mathrm{Cs} \gamma$-ray source (Atomic Energy of Canada Limited, Ottawa, ON, USA) at the specified doses.

Western blot analysis. For western blot analysis of HIF- $1 \alpha$, cells were incubated in $21 \%$ oxygen or $1 \%$ oxygen for $24 \mathrm{~h}$. Samples were collected in RIPA buffer (Sigma-Aldrich) containing Complete Protease Inhibitor Cocktail (Roche, Indianapolis, IN, USA), and protein concentration was determined by Bio-Rad Protein Assay (Bio-Rad, Hercules, CA, USA). Western blot analysis was performed for HIF- $1 \alpha$ using the following antibodies: HIF- $1 \alpha$
(C-Term) Polyclonal Antibody (10006421; Cayman Chemical, Ann Arbor, MI, USA), anti-CD31 (rat monoclonal antibody, DIA-310; Dianova) and $\beta$-actin (A5441; Sigma-Aldrich),

Statistical analysis. Statistical analyses were performed using Microsoft Office Excel 2010 software. P-values were calculated using Student's $t$-test. For comparisons between two or more groups, treatment groups were compared with the control group using one-way ANOVA with Bonferroni adjustment for multiple comparisons. $P$-values $<0.05$ were considered significant.

\section{RESULTS}

Trimodality therapy with hypoxia-activated chemotherapy, VEGF-A inhibition, and radiation. We hypothesised that directing cytotoxic chemotherapy to hypoxic regions within sarcomas would increase the efficacy of VEGF-A inhibition and radiation. We thus examined $\mathrm{TH}-302, \mathrm{DC} 101$, and radiation (aka trimodality therapy) in an HT1080 fibrosarcoma xenograft model. When tumours reached $50-100 \mathrm{~mm}^{3}$, mice were randomised to eight treatment groups (Figure 1A). After 12 days of treatment, trimodality therapy inhibited tumour growth by $91 \%$, which was significantly better than single modality therapies (15-33\%) and bimodality therapies (49-65\%). Mice treated with trimodality therapy did not appear ill and did not lose weight compared with control mice. Treatment of xenografts with trimodality therapy was stopped after 12 days, and tumours were observed. Even after 120 days, tumours treated with trimodality therapy were only an average of $125 \mathrm{~mm}^{3} \pm$ s.d. 12.3 .

After the 12 days of treatment, tumours from each treatment group were harvested and analysed by immunohistochemistry. Representative H\&E sections of tumours from the eight treatment groups are shown in Supplementary Figure S1A. Tumours treated with trimodality therapy had significantly less cellularity and more necrosis compared with control tumours. When tumours were examined for overall apoptosis using TUNEL staining, TH-302 alone resulted in very little total apoptosis (4 cells per 5 fields) (Supplementary Figure S1B). TH-302 in combination with radiation or DC101 resulted in a modest induction of total apoptosis ( 15 cells per 5 fields). Trimodality therapy resulted in significantly more apoptosis (36 cells per 5 fields) compared with $\mathrm{TH}-302$ in combination with radiation or DC101, but trimodality therapy did not cause more apoptosis than bimodality therapy with DC101 and radiation (32 cells per 5 fields). When tumour cells were examined for proliferation using PCNA staining, trimodality therapy led to a $30 \%$ reduction in the number of proliferating tumour cells, while bimodality therapies reduced proliferation by 12-18\% (Supplementary Figure S1C). Thus, there did not appear to be synergistic effects with trimodality therapy on overall apoptosis or proliferation. Given prior studies suggesting that VEGF-A inhibition and radiation have effects on tumour vasculature and hypoxia (Yoon et al, 2011), we next examined microvessel density, endothelial cell-specific apoptosis, and HIF- $1 \alpha$ activity in treated HT1080 tumours. Trimodality therapy led to an $89 \%$ decrease in microvessel density compared with the control tumours (Figure 1B) and a 3.3-fold increase in endothelial cellspecific apoptosis compared with the next best bimodality therapy (Figure 1C). Levels of nuclear HIF-1 $\alpha$ expression and cytoplasmic CA9 expression, as a measure of HIF- $1 \alpha$ target gene activation, were the lowest in tumours treated with trimodality therapy (Figures 1D and E). Thus, trimodality therapy may block growth of HT1080 xenografts as least in part through induction of apoptosis in tumour endothelium and selective ablation of hypoxic cells.

To determine if trimodality therapy would be effective against larger tumours, we again treated HT1080 xenografts with trimodality therapy, but this time waited to initiate therapy until 

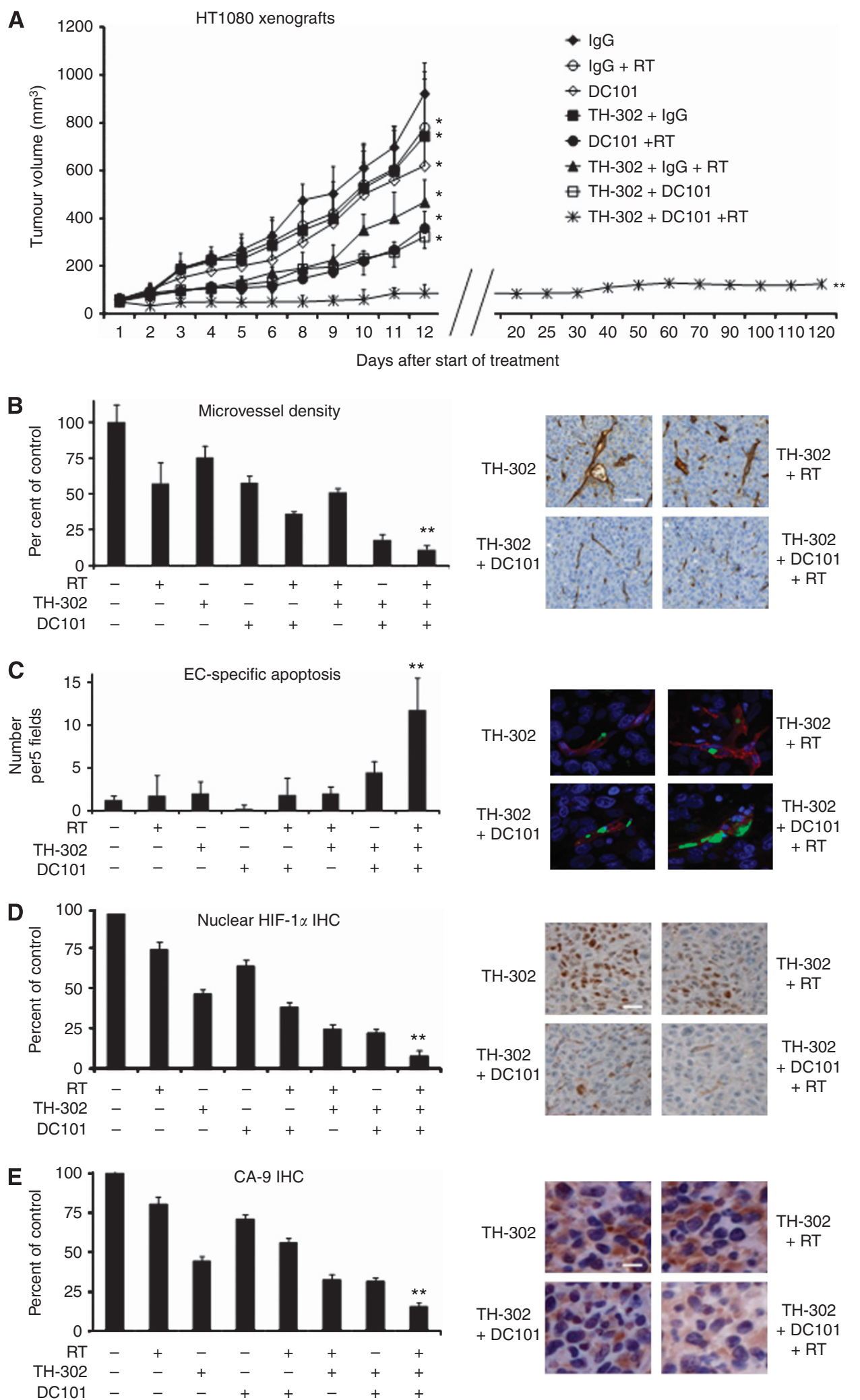

Figure 1. Trimodality therapy in HT1080 xenografts. (A) Growth of HT1080 fibrosarcoma xenografts in athymic nude mice. Groups were treated with control lgG $20 \mathrm{mg} \mathrm{kg}^{-1}$ three times per week, DC101 $20 \mathrm{mg} \mathrm{kg}^{-1}$ three times per week, RT 8 Gy one time, and/or TH-302 $50 \mathrm{mg} \mathrm{kg}{ }^{-1}$ five times per week. Graphs and photos of microvessel density (B), endothelial cell (EC)-specific apoptosis (C), nuclear HIF-1 $\alpha$ expression (D), and cytoplasmic CA-9 expression (E) in HT1080 tumours groups. Scale bars, $20 \mu \mathrm{m}$. Bars represent s.d. $P<0.05$ compared to control group. ${ }^{\star \star} P<0.05$ compared with all other groups.

tumours were about $400 \mathrm{~mm}^{3}$ in size. Mice were then randomised to treatment with vehicle alone or with trimodality therapy. After 2 weeks of treatment, tumours treated with trimodality therapy decreased to an average size of $273 \mathrm{~mm}^{3}$, whereas control tumours grew to an average size of $1209 \mathrm{~mm}^{3}$ (Supplementary Figure S2A). The mean tumour weight of control mice was $545 \mathrm{mg}$ and the 
mean tumour weight of treated mice was $83 \mathrm{mg}$ (Supplementary Figure S2B). Mice were weighed every 2 days during the study, and there was no difference in body weight between control and treated mice (Supplementary Figure S2C). At the end of the treatment period, mice were killed and tumours and blood samples were collected. There was no significant difference in the levels of hemoglobin, white blood cells or platelets between control mice and mice treated with trimodality therapy (Supplementary Figure S2D).

Trimodality therapy has synergistic effects on tumour endothelial cells. Given the significant effects of trimodality therapy on tumour vasculature and HIF- $1 \alpha$ activity, we next wanted to examine trimodality therapy on tumour endothelial cells in vitro. We thus isolated endothelial cells from HT1080 xenografts using magnetic bead separation with CD31 antibody (Figure 2A) and confirmed that these cells upregulated HIF- $1 \alpha$ under hypoxia (Figure 2B). In a proliferation assay, tumour endothelial cells tolerated hypoxia well with proliferation in hypoxia decreasing by only $15 \%$ compared with proliferation in normoxia (Figure $2 \mathrm{C}$ ). Trimodality therapy reduced proliferation under normoxia and hypoxia by $64 \%$ and $87 \%$, respectively (Figure $2 \mathrm{C}$ ). In a colony formation assay, the addition of TH-302 and withdrawal of VEGFA had a minimal effect when added to radiation under normoxic conditions (Figure 2D). In contrast under hypoxia, tumour endothelial cells decreased colony formation by $57 \%$ with $6 \mathrm{~Gy}$ of radiation alone and by $94 \%$ with trimodality therapy. We performed these same studies on HUVECs. In contrast to tumour endothelial cells, HUVECs decrease proliferation by $58 \%$ when grown in hypoxic conditions (Figure 2E). Despite this, we found similar effects of trimodality therapy on HUVEC proliferation (Figure 2E) and colony formation (Figure 2F and Supplementary Figure S3).

To determine if HT1080 xenografts possess areas of hypoxia adjacent to tumour blood vessels, we grew HT1080 xenografts to around $400 \mathrm{~mm}^{3}$ and then treated with either vehicle alone or trimodality therapy for 15 days. At the end of the treatment period, mice were injected with hypoxyprobe and killed. Immunofluorescence on tumour sections for hypoxyprobe and for CD31 showed areas of hypoxia adjacent to CD31-positive tumour blood vessels in both control tumours and in tumours treated with trimodality therapy (Supplementary Figure S4A). The absolute amounts of
A

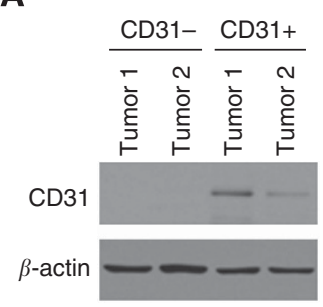

B

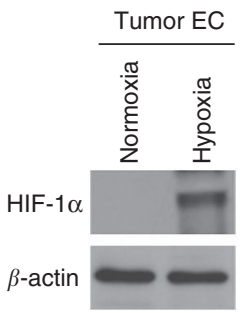

C
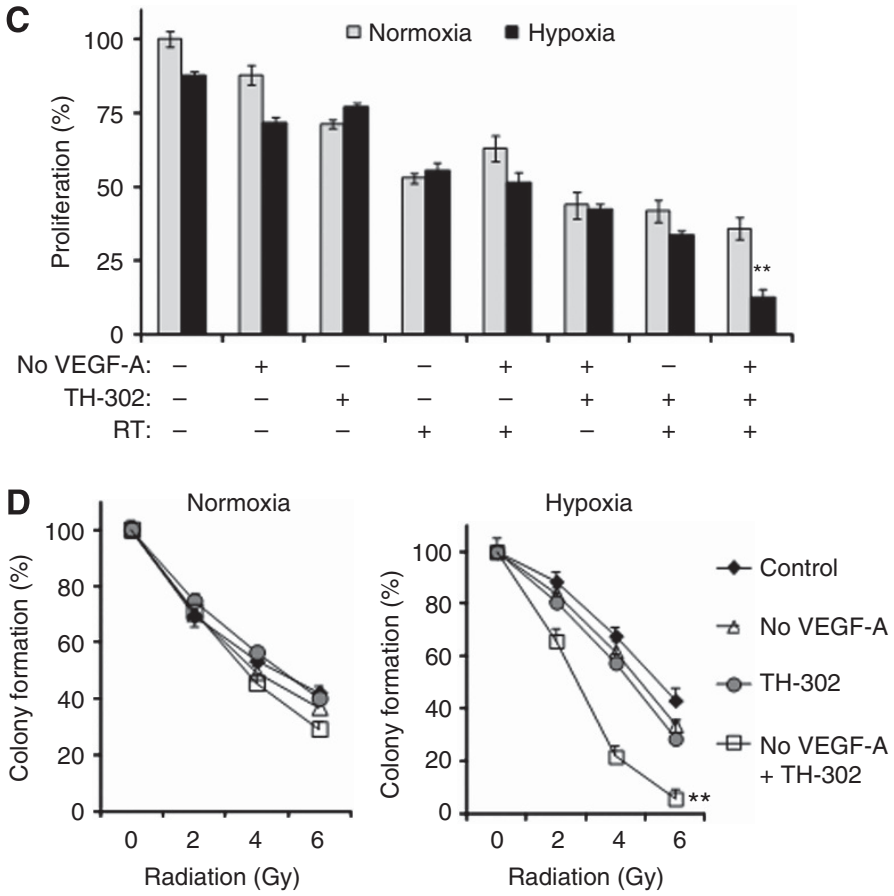

E
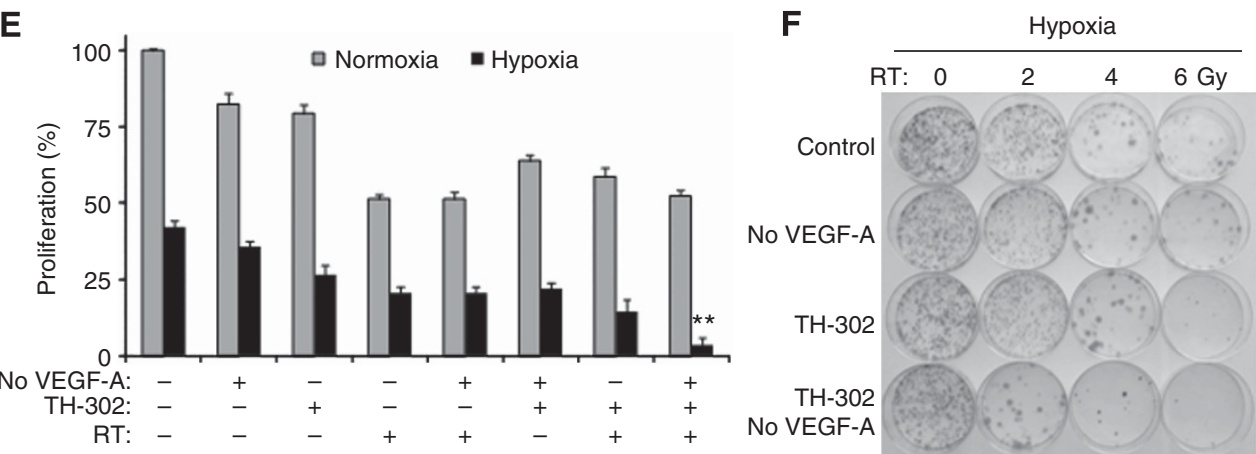

Figure 2. Trimodality therapy in tumour endothelial cells. (A) CD31 western blot of tumour cells following separation by CD31 magnetic beads. (B) Western blot of isolated tumour endothelial cells in normoxia and hypoxia. Proliferation after 3 days (C) and colony formation after 14 days (D) of tumour endothelial cells after withdrawal of VEGF-A (no VEGF-A), RT (0-6 Gy), and/or TH-302 (10 $\mu \mathrm{M})$. Proliferation assay (E) and colon formation assay (F) for HUVEC. Experiments were performed in normoxia and hypoxia. Bars represent standard deviation. ${ }^{\star \star} P<0.05$ compared with all other groups. 
hypoxia and CD31-positive vessels were significantly less in tumours treated with trimodality therapy (Supplementary Figure S4B).

DNA damage and apoptosis in tumour endothelial cells. We next measured DNA damage in tumour endothelial cells by examining the levels of $\gamma \mathrm{H} 2 \mathrm{AX}$ expression and also by using Comet assay. $\gamma \mathrm{H} 2 \mathrm{AX}$ levels increase in response to DNA doublestrand breaks (Lukas et al, 2011). $\gamma \mathrm{H} 2 \mathrm{AX}$ expression in tumour endothelial cells after trimodality therapy was 3.0- to 10.7-fold greater than that after any bimodality therapy when treatment was given under hypoxia (Figures $3 \mathrm{~A}$ and $\mathrm{D}$ ). The effects under normoxia were not nearly as pronounced. In the Comet assay, mean tail moment for trimodality treatment under hypoxic conditions was 3.1- to 5.7-fold greater than any bimodality therapy (Figures $3 \mathrm{~B}$ and $\mathrm{D}$ ). We then determined if DNA damage led to apoptosis by measuring expression of cleaved caspase-3. In hypoxia, cleaved caspase- 3 expression in tumour endothelial cells was 2.3- to 4.8-fold greater following trimodality therapy compared with bimodality therapies (Figures $3 \mathrm{C}$ and D). The effects on apoptosis were much less pronounced under normoxic conditions. These same studies were performed using HUVECs, which also upregulate HIF-1 $\alpha$ under hypoxia (Supplementary Figure S5A), and we found similar results for $\gamma \mathrm{H} 2 \mathrm{AX}$ expression (Supplementary Figures S5B and D) and cleaved caspase-3 expression (Supplementary Figures S5C and D).

Cancer cell autonomous effects. We next evaluated the cancer cell autonomous effects of trimodality therapy on four sarcoma cell lines in vitro. Vascular endothelial growth factor-A addition or withdrawal had no effect on proliferation or colony formation of sarcoma cell lines (data not shown), and thus experiments on these cell lines were conducted without VEGF-A. All four sarcoma cell lines upregulated HIF- $1 \alpha$ under hypoxia (Supplementary Figure S6A). We found that combining TH-302 and radiation had a modest effect in blocking proliferation in both normoxia and hypoxia (Figure 4A). We also examined colony formation in these four sarcoma cell lines in response to TH-302 and radiation under both normoxic and hypoxic conditions and again found only minimal increase with combination therapy (Figure 4B and Supplementary Figure $\mathrm{S} 6 \mathrm{~B})$. The combination of $\mathrm{TH}-302$ and radiation did result in increases in DNA damage as measured by $\gamma \mathrm{H} 2 \mathrm{AX}$ expression

A

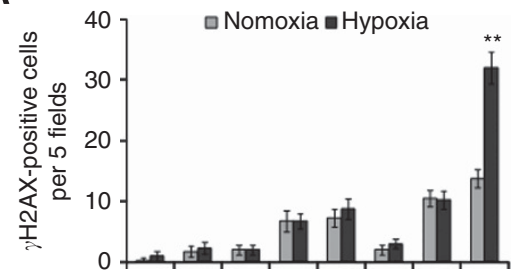

C

B

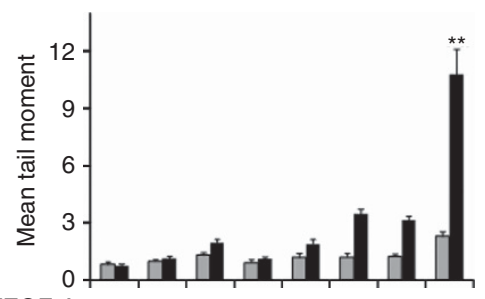

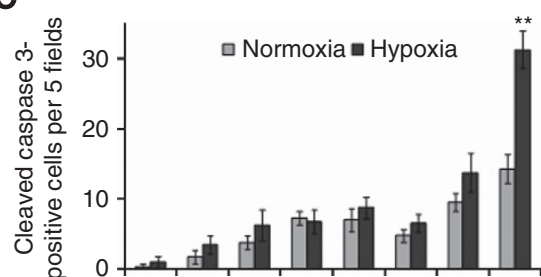

No VEGF-A: - + - -++-+

TH-302: $-\quad+\quad+-\quad+++$

RT: $-\quad-\quad++-++$
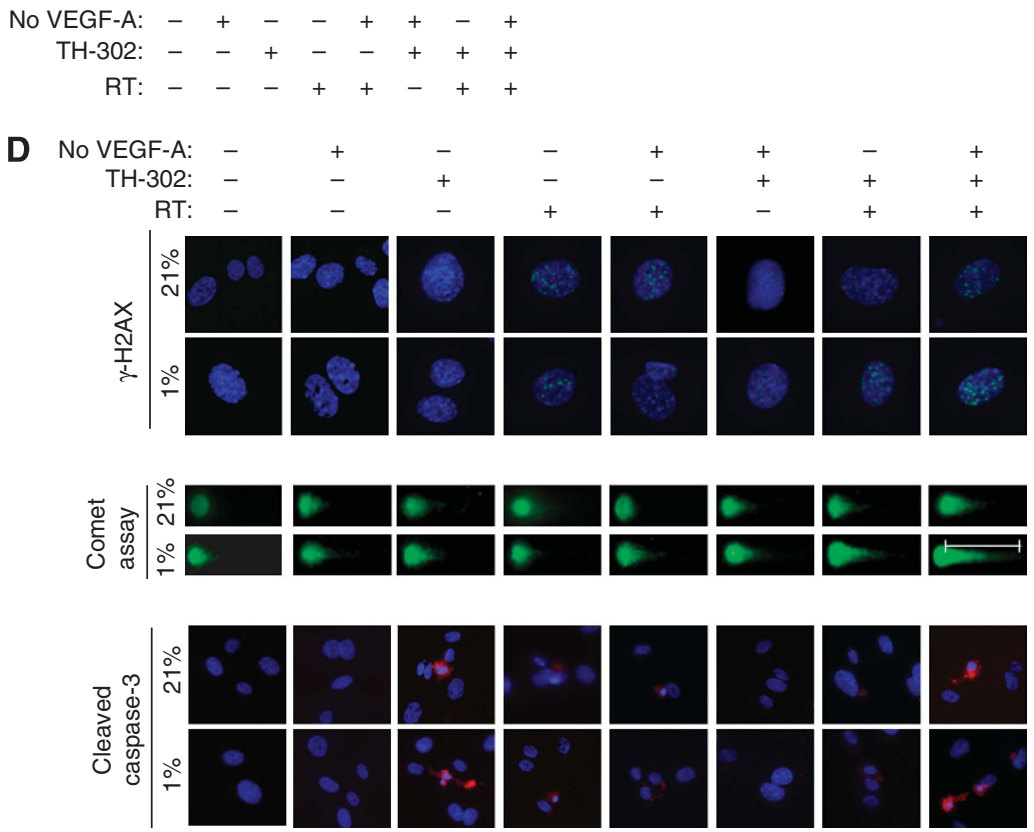

Figure 3. DNA damage and apoptosis in tumour endothelial cells. Graphs showing $\gamma \mathrm{H} 2 \mathrm{AX}$ expression (A), Comet assay mean tail moment (B), and cleaved caspase-3 expression (C) of tumour endothelial cells following withdrawal of VEGF-A (no VEGF), RT (6 Gy), and/or TH-302 (10 $\mu \mathrm{m})$. All experiments were performed in normoxia $\left(21 \% \mathrm{O}_{2}\right)$ and hypoxia $\left(1 \% \mathrm{O}_{2}\right)$. Bars represent s.d. (D) Immunofluorescence photos of tumour endothelial cells following $\gamma \mathrm{H} 2 \mathrm{AX}$ immunofluorescence (green), Comet assay, and cleaved caspase-3 immunofluorescence (red). Nuclei were stained with DAPI (4',6-diamidino-2-phenylindole; blue). Bars represent s.d. ${ }^{\star \star} P<0.05$ compared with all other groups. 
A
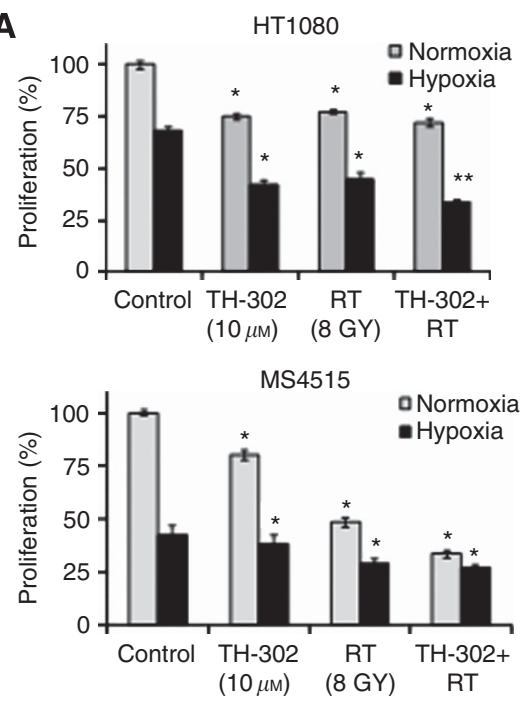

B

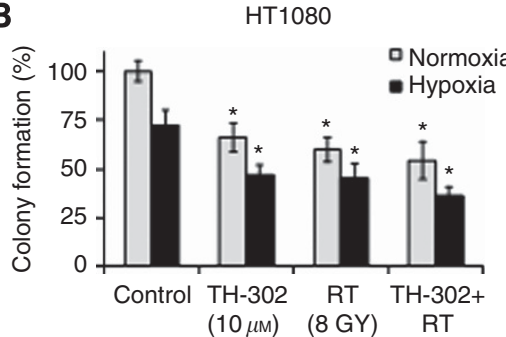

MS4515
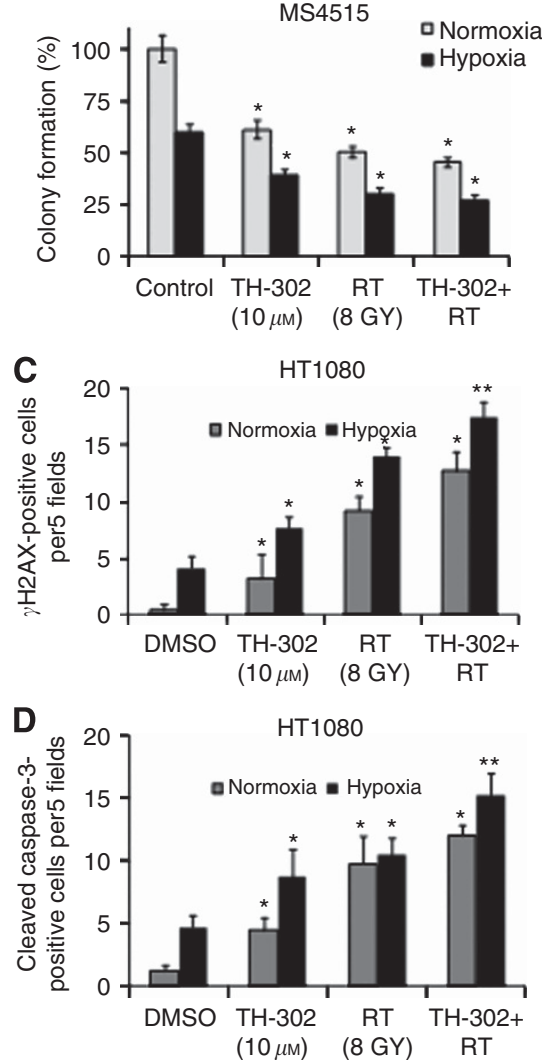
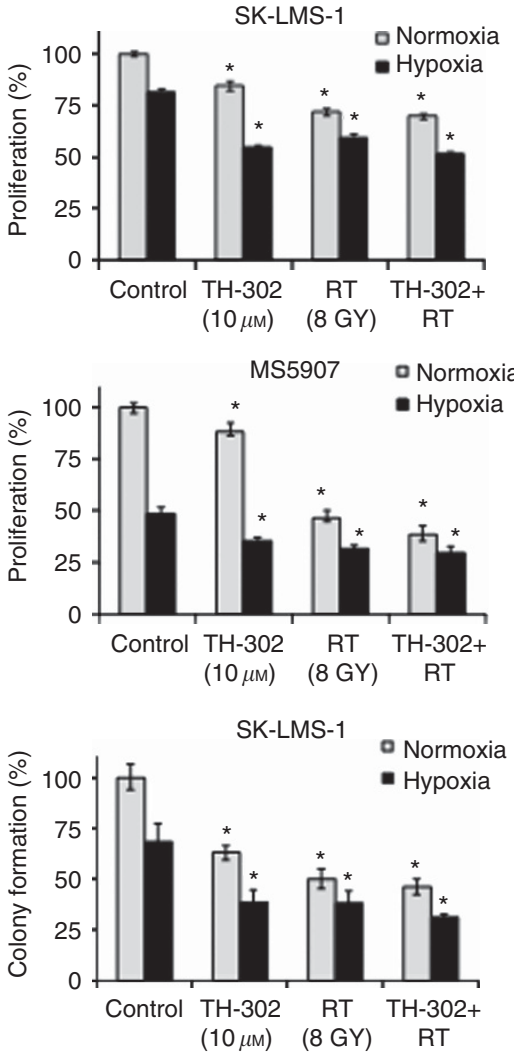

MS5907

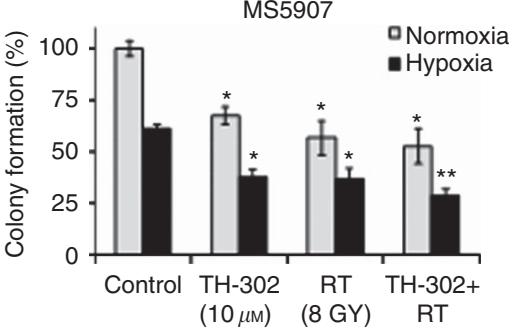

MS4515

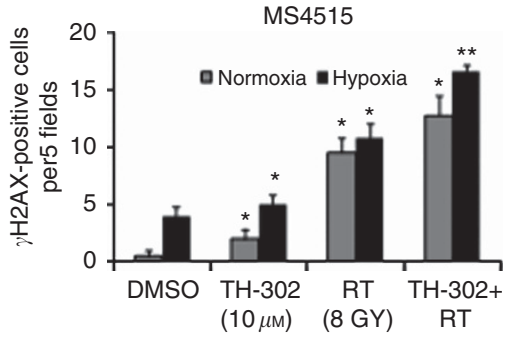

MS4515

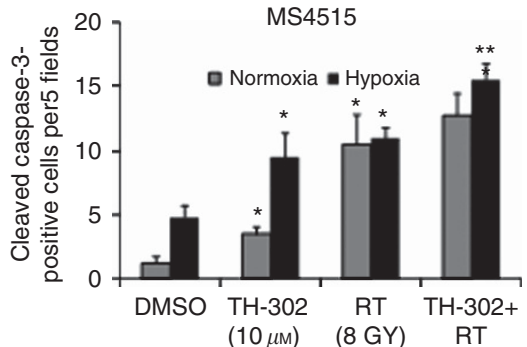

Figure 4. Trimodality therapy in sarcoma cells. Proliferation assay (A), colony formation assay (B), $\gamma \mathrm{H} 2 \mathrm{AX}$ expression (C) and cleaved caspase-3 expression in HT1080 and SK-LMS-1 human sarcoma cells and MS4515 and MS5907 mouse sarcoma cells after RT (8 Gy) and/or TH-302 (10 $\mu \mathrm{M})$. All experiments were carried out in normoxia and hypoxia. Bars represent s.d. ${ }^{*} P<0.05$ compared with control. ${ }^{\star *} P<0.05$ compared with all other groups. 
A

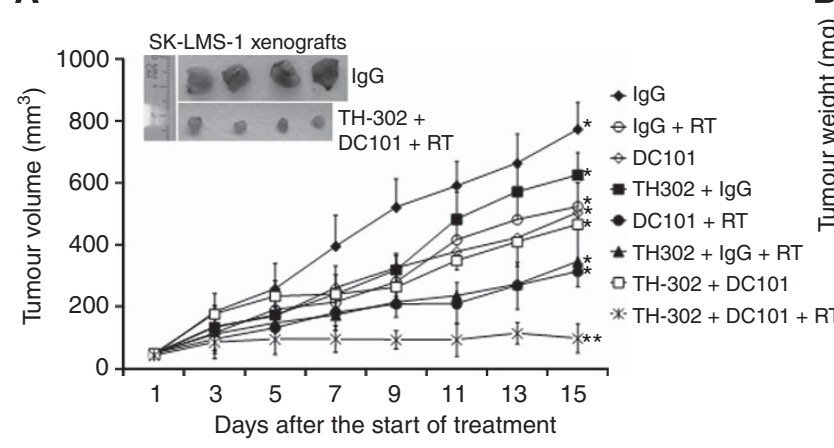

B

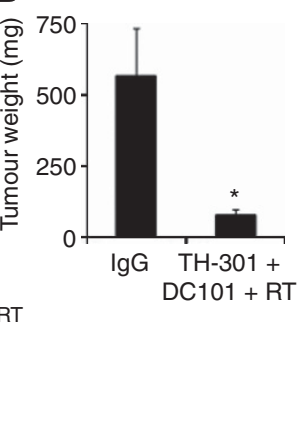

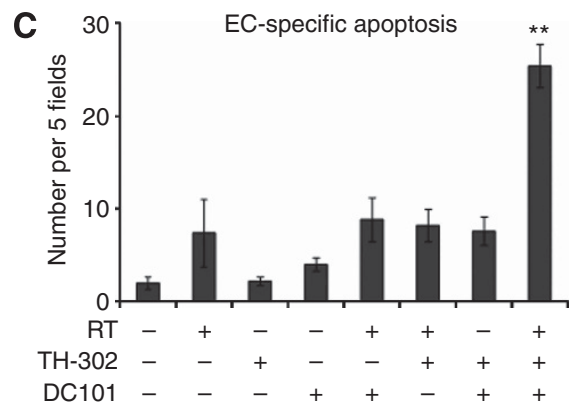
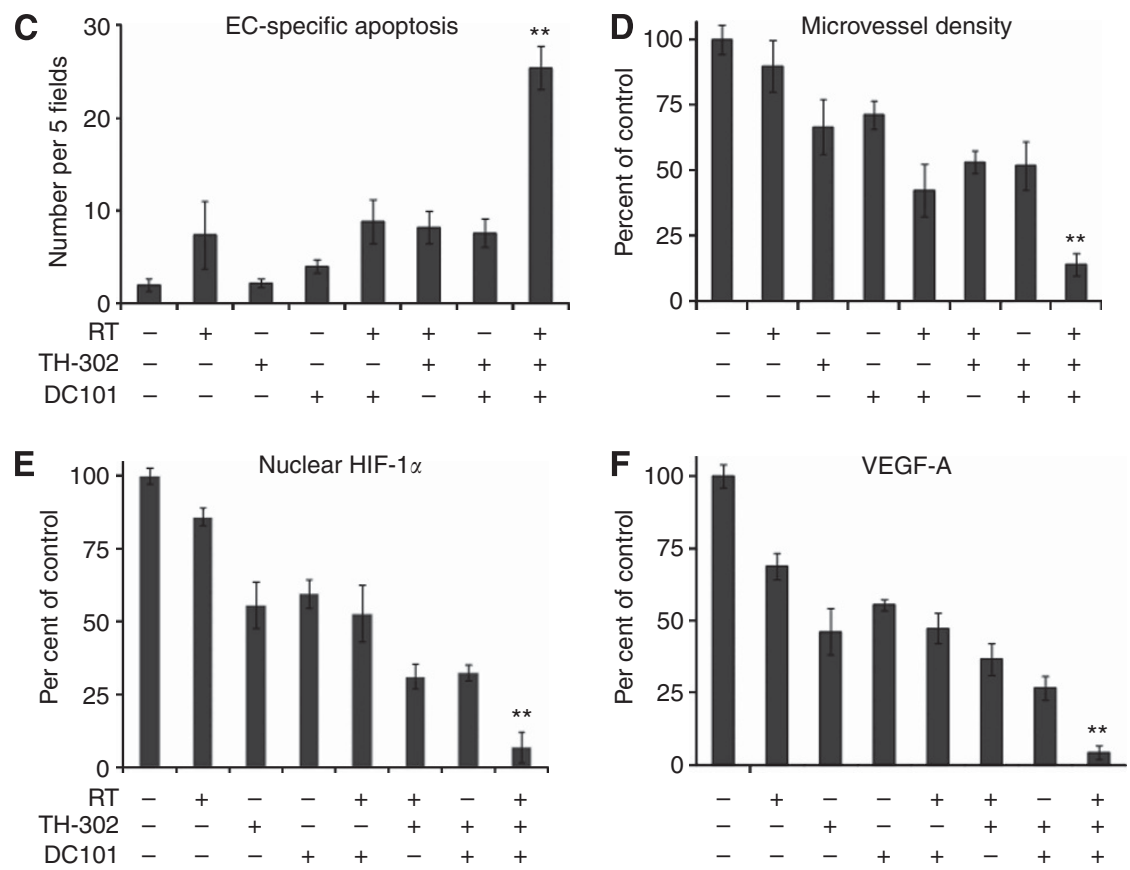

Figure 5. Trimodality therapy in SK-LMS-1 xenografts. (A) Growth of SK-LMS-1 leiomyosarcoma xenografts in athymic nude mice. Groups were treated with control immunoglobulin $\mathrm{G}(\mathrm{lgG}) 20 \mathrm{mg} \mathrm{kg}^{-1}$ three times per week, DC101 $20 \mathrm{mg} \mathrm{kg}^{-1}$ three times per week, RT $8 \mathrm{~Gy}$ one time, and/or TH-302 $50 \mathrm{mg} \mathrm{kg}^{-1}$ five times per week. (B) Tumour weight. Graphs of endothelial-specific apoptosis (C), microvessel density (D), nuclear HIF-1 $\alpha$ expression (E), and VEGF-A expression $(\mathrm{F})$ in SK-LMS-1 tumour groups. Bars represent s.d. * $P<0.05$ compared with IgG control. ${ }^{\star \star} P<0.05$ compared with all other groups.

(Figure 4C and Supplementary Figure S6C) and apoptosis as measured by cleaved caspase-3 expression (Figure $4 \mathrm{D}$ and Supplementary Figure S6D). However, these effects were not nearly as pronounced as the effects seen in tumour endothelial cells.

Trimodality therapy in SK-LMS-1 leiomyosarcoma xenografts. To confirm the effects of trimodality therapy in a different type of sarcoma, we performed another mouse xenograft study using SKLMS-1 leiomyosarcoma cells. Mice were again randomised to eight treatment groups after tumours reached $50-100 \mathrm{~mm}^{3}$ (Figure 5A). Following 15 days of treatment, average tumour size and weight for the trimodality therapy group was $98 \mathrm{~mm}^{3}$ and $79 \mathrm{mg}$, respectively, compared with control tumours that were $774 \mathrm{~mm}^{3}$ and $567 \mathrm{mg}$, respectively (Figures 5A and $\mathrm{B}$ ). When tumours were harvested and analysed, trimodality therapy was found to have more than additive effects on microvessel density, endothelial cell-specific apoptosis, microvessel density, HIF- $1 \alpha$ nuclear expression, and VEGF-A expression (Figures 5C-F).

Multicolor immunofluorescence for $\gamma \mathrm{H} 2 \mathrm{AX}$, cleaved caspase-3, and CD31 was performed on treated SK-LMS-1 tumours to quantify the number of endothelial cells and non-endothelial cells exhibiting DNA damage and apoptosis. Trimodality therapy led to marked increases in both endothelial cells and non-endothelial tumour cells demonstrating both $\gamma \mathrm{H} 2 \mathrm{AX}$ and cleaved caspase- 3 expression (Figures $6 \mathrm{~A}-\mathrm{C}$ ). The absolute number of $\mathrm{CD} 31(+)$ cells per 5 visual fields demonstrating $\gamma \mathrm{H} 2 \mathrm{AX}$ and cleaved caspase3 expression was 13.2 after trimodality therapy compared with 2.8-3.4 after bimodality therapies. Interestingly, CD31( -$)$ cells also showed more than additive increases in $\gamma \mathrm{H} 2 \mathrm{AX}(-)$ and cleaved caspase- $3+$ cells ( 9.2 vs 3.0-4.0 cells per 5 fields). Given our in vitro studies in sarcoma cell lines showed at most additive effects of trimodality therapy on $\gamma \mathrm{H} 2 \mathrm{AX}$ and cleaved caspase- 3 expression, the results of our SK-LMS-1 tumour analysis suggest that the efficacy of trimodality therapy may depend on in vivo interaction of the endothelial cell compartment and tumour cell compartment. We found similar results when we performed this multicolor immunofluorescence analysis on HT1080 tumours treated with trimodality therapy (Figures 6D-F). The absolute number of $\mathrm{CD} 31(+)$ cells per 5 visual fields demonstrating $\gamma \mathrm{H} 2 \mathrm{AX}$ and cleaved caspase- 3 expression was 12.4 after trimodality therapy compared with 3.2-4.2 after bimodality therapies. CD31 (-) had 10.2 cells per 5 fields with both $\gamma \mathrm{H} 2 \mathrm{AX}(-)$ and cleaved caspase-3 $(+)$ after trimodality therapy and 4.4-5.0 cells per 5 fields after bimodality therapies. 
A

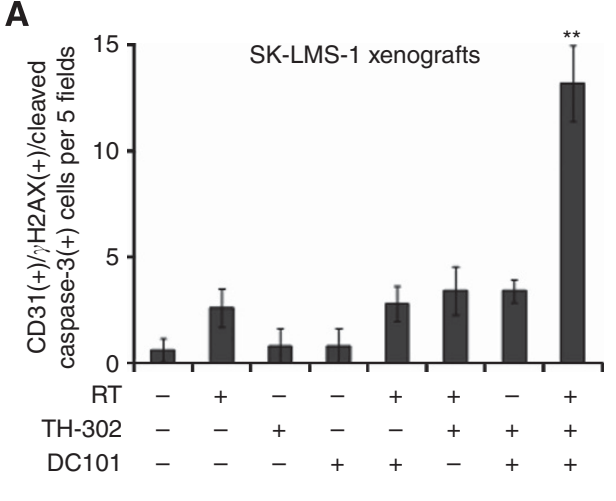

\section{B}

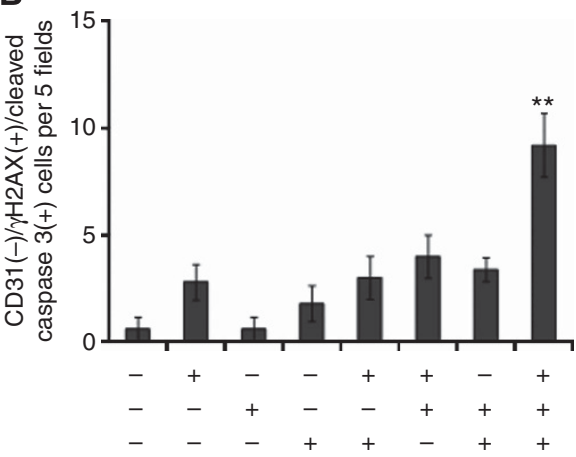

$\begin{array}{lllll}\text { C RT } & - & + & - & - \\ \text { TH-302 } & - & - & + & - \\ \text { DC101 } & - & - & - & +\end{array}$

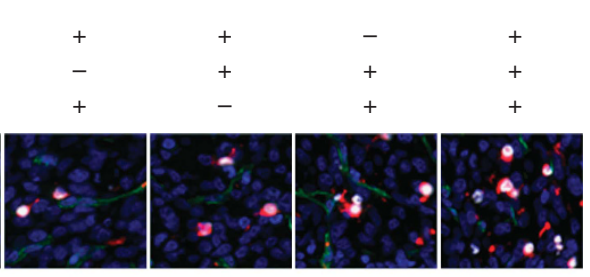

CD31 үH2AX Cleaved caspase-3

D

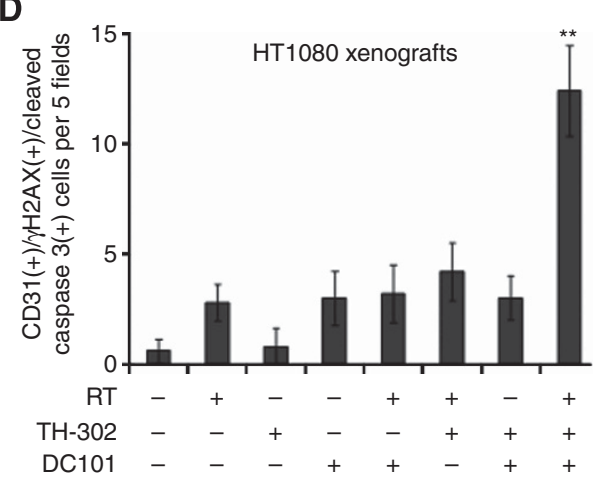

E

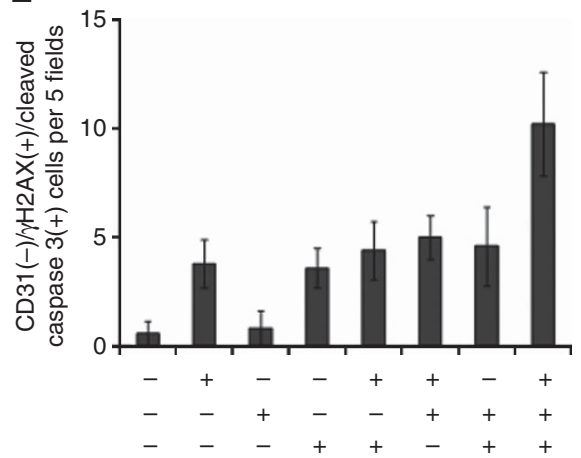

$\mathbf{F}$
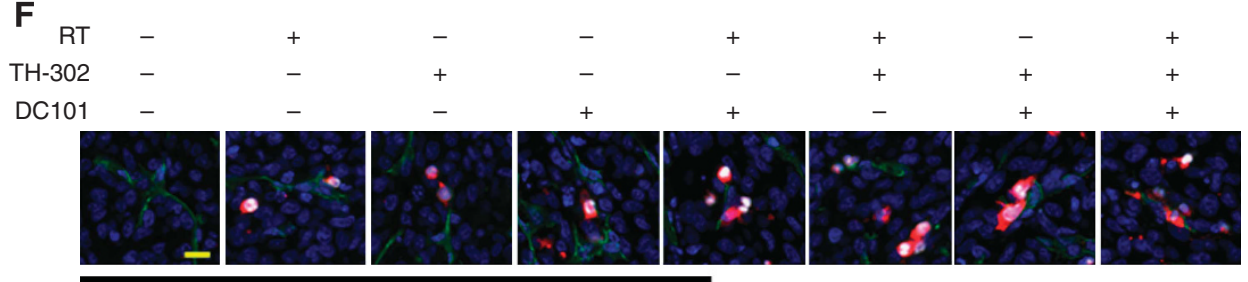

CD31 yH2AX Cleaved caspase-3

Figure 6. DNA damage and apoptosis in SK-LMS-1 and HT1080 xenografts. Graphs demonstrating the number of $\mathrm{CD} 31+/ \gamma \mathrm{H} 2 \mathrm{AX}+/ \mathrm{cleaved}$ caspase- $3+$ cells $(\mathbf{A})$ and CD31 - / $\gamma \mathrm{H} 2 \mathrm{AX}+/$ cleaved caspase- $3+$ cells (B) in SK-LMS-1 tumours from each treatment group. (C)

Immunofluorescence photos of tumours from each treatment group after staining for CD31 (green), $\gamma \mathrm{H} 2 \mathrm{AX}$ (white), cleaved caspase-3 (red), and nuclei (DAPI, 4',6-diamidino-2-phenylindole). Graphs demonstrating the number of CD31 $/ / \gamma \mathrm{H} 2 \mathrm{AX}+/$ cleaved caspase-3 + cells (D) and CD31 - / $\gamma \mathrm{H} 2 \mathrm{AX}+$ /cleaved caspase-3 + cells (E) in HT1080 tumours from each treatment group. (E) Immunofluorescence photos of tumours from each treatment group after staining for CD31 (green), $\gamma \mathrm{H} 2 \mathrm{AX}$ (white), cleaved caspase-3 (red), and nuclei (DAPI). Bars represent standard deviation. Scale bar, $20 \mu \mathrm{m} .{ }^{\star \star} P<0.05$ compared with all other groups.

\section{DISCUSSION}

In this study, we examined the addition of TH-302, a hypoxiaactivated chemotherapy, to VEGF-A inhibition and radiation. We found that this trimodality therapy blocked growth of HT1080 and SK-LMS-1 sarcoma xenografts significantly better than VEGF-A inhibition and radiation, and analysis of tumour samples and in vitro studies revealed that one primary mechanism of action was the induction of endothelial cell DNA damage and apoptosis resulting in loss of tumour vasculature. This induction of DNA damage and apoptosis was also seen in HT1080 and SK-LMS-1 cancer cells but to a lesser extent.

As noted earlier, $\mathrm{TH}-302$ is a 2 -nitroimidazole-linked prodrug of Br-IPM (Duan et al, 2008). The 2-nitroimidazole moiety of TH302 is a substrate for intracellular 1-electron reductases and, when reduced in deeply hypoxic conditions, releases Br-IPM. In vitro cytotoxicity and clonogenic assays using human cancer cell lines show that TH-302 has little cytotoxic activity under normoxic conditions and greatly enhanced cytotoxic potency under hypoxic conditions. The activated prodrug works as a DNA crosslinking agent and is able to kill both nondividing and dividing cells. 
TH-302 enhances the activity of a wide range of chemotherapy drugs in numerous xenograft models including HT1080 xenografts (Liu et al, 2012; Sun et al, 2012b), and has been found to be a promising agent in combination with doxorubicin for patients with metastatic sarcoma (Chawla et al, 2014). Saggar and Tannock (2014) found in two xenograft models that TH-302 combined with chemotherapy increases DNA damage and apoptosis throughout the tumour (Saggar and Tannock, 2014). TH-302 was found to be more effective in cell lines deficient in homologous recombination secondary to mutations in BRCA1 or BRCA2 (Meng et al, 2012; Hunter et al, 2014). A phase III randomised trial of doxorubicin with or without TH-302 in patients with soft tissue sarcoma completed enrolment and results are pending.

Mechanisms of resistance to antiangiogenic therapies include: upregulation of alternative proangiogenic signals, protection of the tumour vasculature either by recruiting proangiogenic inflammatory cells or by increasing protective pericyte coverage, accentuated invasiveness of tumour cells into local tissue to co-opt normal vasculature, and increased metastatic seeding and tumour cell growth in lymph nodes and distant organs (Bergers and Hanahan, 2008). Upregulation of HIF- $1 \alpha$ and HIF- $1 \alpha$ target genes in response to hypoxia may contribute to all these resistance mechanisms. Casanovas et al (2005) found that VEGFR-2 inhibition of RIP1-Tag2 mouse pancreatic endocrine tumours led to an increase in intratumoral hypoxia along with increased tumour invasiveness and liver metastases (Paez-Ribes et al, 2009), and Ebos et al (2009) found that sunitinib (which targets VEGF and other pathways) increased liver and lung metastases for both experimental and spontaneous metastases. Given the heterogeneity and genetic instability of tumours, combination of different therapies that target primary pathways as well as resistance pathways is a rational approach. This study demonstrates that destruction of hypoxic regions within tumours using TH-302 complements anti-VEGF-A therapy and radiation in sarcomas.

The mechanisms by which anti-VEGF agents may augment the efficacy of radiation include 'vascular normalisation' of abnormally dilated and permeable tumour vessels leading to increased oxygenation (Jain, 2001) and augmentation of endothelial cell cytotoxicity (Gupta et al, 2002). Tumour response to radiation may be regulated by endothelial cell apoptosis (Garcia-Barros et al, 2003). Although VEGF-A inhibition has effects primarily on endothelial cells, TH-302 under hypoxic conditions will have cytotoxic effects via DNA alkylation on both cancer cells and tumour endothelial cells. In this study, we found the ability of trimodality therapy with TH-302, VEGF-A inhibition, and radiation to block tumour growth is primarily through induction of endothelial cell DNA damage and apoptosis rather than cancer cells autonomous effects.

There are several limitations to this study. First, sarcomas are a heterogeneous group of tumours comprised of over 80 histologic subtypes, and thus the results of this study may not be applicable to all sarcoma subtypes. However, we examined two xenograft models of sarcoma, two types of endothelial cells, and four sarcoma cell lines, and found generally consistent results. Moreover, the predominant effect of these trimodality therapies appears to be on the tumour vasculature, and thus cancer cell autonomous variations in sarcoma subtypes may be less important. Second, in this study we examined proliferation, colony formation, apoptosis, and DNA damage in cancer cells and endothelial cells but did not examine alternative mechanisms or effects on other cells in the tumour microenvironment. Such studies are currently ongoing but beyond the scope of this study.

In conclusion, most solid tumours including sarcomas rely on several oncogenic pathways to drive tumour growth and to induce the tumour microenvironment to support this growth. Given the versatility of these tumours, blockade of a single pathway may have little effect or a transient effect as compensatory and resistance mechanisms become activated. Thus, combination therapies that target primary and secondary pathways make intuitive sense. This study describes a three-pronged strategy to block the growth of sarcomas: radiation to induce endothelial cell DNA damage and apoptosis, VEGF-A inhibition to block the major survival factor for endothelial cells, and hypoxia-activated chemotherapy to eradicate hypoxic cells and block the hypoxic tumour response. In vivo and in vitro studies confirm that this trimodality approach leads to marked induction of endothelial cell DNA damage and apoptosis and vastly decreased tumour vasculature. Thus, this article provides a preclinical foundation for the use of this strategy in clinical trials.

\section{ACKNOWLEDGEMENTS}

This work was supported by NIH Grants 1R21 CA117128-02 (SSY) and 1R01 CA158301-01 (SSY and MCS), and the Society for Surgical Oncology Clinical Investigator Award (SSY).

\section{REFERENCES}

UKCCCR (2000) UKCCCR guidelines for the use of cell lines in cancer research. Br J Cancer 82(9): 1495-1509.

Bergers G, Hanahan D (2008) Modes of resistance to anti-angiogenic therapy. Nat Rev Cancer 8(8): 592-603.

Bertout JA, Patel SA, Simon MC (2008) The impact of $\mathrm{O}_{2}$ availability on human cancer. Nat Rev Cancer 8(12): 967-975.

Brennan MF, Antonescu CR, Maki RG (2013) Management of Soft Tissue Sarcoma. Springer: New York, NY, USA.

Casanovas O, Hicklin DJ, Bergers G, Hanahan D (2005) Drug resistance by evasion of antiangiogenic targeting of VEGF signaling in late-stage pancreatic islet tumors. Cancer Cell 8(4): 299-309.

Chawla SP, Cranmer LD, Van Tine BA, Reed DR, Okuno SH, Butrynski JE, Adkins DR, Hendifar AE, Kroll S, Ganjoo KN (2014) Phase II Study of the safety and antitumor activity of the hypoxia-activated prodrug TH-302 in combination with doxorubicin in patients with advanced soft tissue sarcoma. J Clin Oncol 32(29): 3299-3306.

Detwiller KY, Fernando NT, Segal NH, Ryeom SW, D’Amore PA, Yoon SS (2005) Analysis of hypoxia-related gene expression in sarcomas and effect of hypoxia on RNA interference of vascular endothelial cell growth factor A. Cancer Res 65(13): 5881-5889.

Duan JX, Jiao H, Kaizerman J, Stanton T, Evans JW, Lan L, Lorente G, Banica M, Jung D, Wang J, Ma H, Li X, Yang Z, Hoffman RM, Ammons WS, Hart CP, Matteucci M (2008) Potent and highly selective hypoxiaactivated achiral phosphoramidate mustards as anticancer drugs. $\mathrm{J} \mathrm{Med}$ Chem 51(8): 2412-2420.

Dvorak HF (2002) Vascular permeability factor/vascular endothelial growth factor: a critical cytokine in tumor angiogenesis and a potential target for diagnosis and therapy. J Clin Oncol 20(21): 4368-4380.

Ebos JM, Lee CR, Cruz-Munoz W, Bjarnason GA, Christensen JG, Kerbel RS (2009) Accelerated metastasis after short-term treatment with a potent inhibitor of tumor angiogenesis. Cancer Cell 15(3): 232-239.

Fernando NT, Koch M, Rothrock C, Gollogly LK, D'Amore PA, Ryeom S, Yoon SS (2008) Tumor escape from endogenous, extracellular matrixassociated angiogenesis inhibitors by up-regulation of multiple proangiogenic factors. Clin Cancer Res 14(5): 1529-1539.

Garcia-Barros M, Paris F, Cordon-Cardo C, Lyden D, Rafii S, HaimovitzFriedman A, Fuks Z, Kolesnick R (2003) Tumor response to radiotherapy regulated by endothelial cell apoptosis. Science 300(5622): 1155-1159.

Gupta VK, Jaskowiak NT, Beckett MA, Mauceri HJ, Grunstein J, Johnson RS, Calvin DA, Nodzenski E, Pejovic M, Kufe DW, Posner MC, Weichselbaum RR (2002) Vascular endothelial growth factor enhances endothelial cell survival and tumor radioresistance. Cancer J 8(1): 47-54.

Hoffmann AC, Danenberg KD, Taubert H, Danenberg PV, Wuerl P (2009) A three-gene signature for outcome in soft tissue sarcoma. Clin Cancer Res 15(16): 5191-5198.

Hunter FW, Hsu HL, Su J, Pullen SM, Wilson WR, Wang J (2014) Dual targeting of hypoxia and homologous recombination repair dysfunction in triple-negative breast cancer. Mol Cancer Ther 13(11): 2501-2514. 
Jain RK (2001) Normalizing tumor vasculature with anti-angiogenic therapy: a new paradigm for combination therapy. Nat Med 7(9): 987-989.

Kim YJ, Lee HJ, Kim TM, Eisinger-Mathason TS, Zhang AY, Schmidt B, Karl DL, Nakazawa MS, Park PJ, Simon MC, Yoon SS (2013) Overcoming evasive resistance from vascular endothelial growth factor a inhibition in sarcomas by genetic or pharmacologic targeting of hypoxia-inducible factor 1alpha. Int J Cancer 132(1): 29-41.

Kirsch DG, Dinulescu DM, Miller JB, Grimm J, Santiago PM, Young NP, Nielsen GP, Quade BJ, Chaber CJ, Schultz CP, Takeuchi O, Bronson RT, Crowley D, Korsmeyer SJ, Yoon SS, Hornicek FJ, Weissleder R, Jacks T (2007) A spatially and temporally restricted mouse model of soft tissue sarcoma. Nat Med 13(8): 992-997.

Lahat G, Lazar A, Lev D (2008) Sarcoma epidemiology and etiology: potential environmental and genetic factors. Surg Clin N Am 88(3): 451-481.

Liu Q, Sun JD, Wang J, Ahluwalia D, Baker AF, Cranmer LD, Ferraro D, Wang Y, Duan JX, Ammons WS, Curd JG, Matteucci MD, Hart CP (2012) TH-302, a hypoxia-activated prodrug with broad in vivo preclinical combination therapy efficacy: optimization of dosing regimens and schedules. Cancer Chemother Pharmacol 69(6): 1487-1498.

Lukas J, Lukas C, Bartek J (2011) More than just a focus: the chromatin response to DNA damage and its role in genome integrity maintenance. Nat Cell Biol 13(10): 1161-1169.

Meng F, Evans JW, Bhupathi D, Banica M, Lan L, Lorente G, Duan JX, Cai X, Mowday AM, Guise CP, Maroz A, Anderson RF, Patterson AV, Stachelek GC, Glazer PM, Matteucci MD, Hart CP (2012) Molecular and cellular pharmacology of the hypoxia-activated prodrug TH-302. Mol Cancer Ther 11(3): 740-751.

Paez-Ribes M, Allen E, Hudock J, Takeda T, Okuyama H, Vinals F, Inoue M, Bergers G, Hanahan D, Casanovas O (2009) Antiangiogenic therapy elicits malignant progression of tumors to increased local invasion and distant metastasis. Cancer Cell 15(3): 220-231.

Potter C, Harris AL (2004) Hypoxia inducible carbonic anhydrase IX, marker of tumour hypoxia, survival pathway and therapy target. Cell Cycle 3(2): 164-167.

Ryeom S, Baek KH, Rioth MJ, Lynch RC, Zaslavsky A, Birsner A, Yoon SS, McKeon F (2008) Targeted deletion of the calcineurin inhibitor DSCR1 suppresses tumor growth. Cancer Cell 13(5): 420-431.

Saggar JK, Tannock IF (2014) Activity of the hypoxia-activated pro-drug TH302 in hypoxic and perivascular regions of solid tumors and its potential to enhance therapeutic effects of chemotherapy. Int J Cancer 134(11): 2726-2734.

Schuetze SM, Patel S (2009) Should patients with high-risk soft tissue sarcoma receive adjuvant chemotherapy? Oncologist 14(10): 1003-1012.

Semenza GL (1999) Regulation of mammalian $\mathrm{O}_{2}$ homeostasis by hypoxiainducible factor 1. Annu Rev Cell Dev Biol 15: 551-578.

Shannon AM, Williams KJ (2008) Antiangiogenics and radiotherapy. J Pharm Pharmacol 60(8): 1029-1036.
Sun JD, Liu Q, Wang J, Ahluwalia D, Ferraro D, Wang Y, Duan JX, Ammons WS, Curd JG, Matteucci MD, Hart CP (2012a) Selective tumor hypoxia targeting by hypoxia-activated prodrug TH-302 inhibits tumor growth in preclinical models of cancer. Clin Cancer Res 18(3): 758-770.

Sun JD, Liu Q, Wang J, Ahluwalia D, Ferraro D, Wang Y, Duan JX, Ammons WS, Curd JG, Matteucci MD, Hart CP (2012b) Selective tumor hypoxia targeting by hypoxia-activated prodrug TH-302 inhibits tumor growth in preclinical models of cancer. Clin Cancer Res 18(3): 758-770.

Truman JP, Garcia-Barros M, Kaag M, Hambardzumyan D, Stancevic B, Chan M, Fuks Z, Kolesnick R, Haimovitz-Friedman A (2010) Endothelial membrane remodeling is obligate for anti-angiogenic radiosensitization during tumor radiosurgery. PLoS One 5(9): doi:10.1371/annotation/ 6e222ad5-b175-4a00-9d04-4d120568a897.

van der Graaf WT, Blay JY, Chawla SP, Kim DW, Bui-Nguyen B, Casali PG, Schoffski P, Aglietta M, Staddon AP, Beppu Y, Le CA, Gelderblom H, Judson IR, Araki N, Ouali M, Marreaud S, Hodge R, Dewji MR, Coens C, Demetri GD, Fletcher CD, Dei Tos AP, Hohenberger P (2012) Pazopanib for metastatic soft-tissue sarcoma (PALETTE): a randomised, double-blind, placebo-controlled phase 3 trial. Lancet 379(9829): 1879-1886.

Wachsberger P, Burd R, Dicker AP (2003) Tumor response to ionizing radiation combined with antiangiogenesis or vascular targeting agents: exploring mechanisms of interaction. Clin Cancer Res 9(6): 1957-1971.

Yoon SS, Duda DG, Karl DL, Kim TM, Kambadakone AR, Chen YL, Rothrock C, Rosenberg AE, Nielsen GP, Kirsch DG, Choy E, Harmon DC, Hornicek FJ, Dreyfuss J, Ancukiewicz M, Sahani DV, Park PJ, Jain RK, DeLaney TF (2011) Phase II study of neoadjuvant bevacizumab and radiotherapy for resectable soft tissue sarcomas. Int J Radiat Oncol Biol Phys 81(4): 10811090.

Yoon SS, Eto H, Lin CM, Nakamura H, Pawlik TM, Song SU, Tanabe KK (1999) Mouse endostatin inhibits the formation of lung and liver metastases. Cancer Res 59(24): 6251-6256.

Yoon SS, Segal NH, Olshen AB, Brennan MF, Singer S (2004) Circulating angiogenic factor levels correlate with extent of disease and risk of recurrence in patients with soft tissue sarcoma. Ann Oncol 15(8): 12611266.

Yoon SS, Stangenberg L, Lee YJ, Rothrock C, Dreyfuss JM, Baek KH, Waterman PR, Nielsen GP, Weissleder R, Mahmood U, Park PJ, Jacks T, Dodd RD, Fisher CJ, Ryeom S, Kirsch DG (2009) Efficacy of sunitinib and radiotherapy in genetically engineered mouse model of soft-tissue sarcoma. Int J Radiat Oncol Biol Phys 74(4): 1207-1216.

This work is published under the standard license to publish agreement. After 12 months the work will become freely available and the license terms will switch to a Creative Commons AttributionNonCommercial-Share Alike 4.0 Unported License.

Supplementary Information accompanies this paper on British Journal of Cancer website (http://www.nature.com/bjc) 